\title{
ARTICLE
}

\section{Variation in Black Bass Angler Characteristics by Stream Size and Accessibility in Oklahoma's Ozark Highland Streams}

\author{
Binod P. Chapagain* \\ Department of Natural Resource Ecology and Management, Oklahoma State University, Stillwater, Oklahoma 74078, \\ $U S A$
}

James M. Long

U.S. Geological Survey, Oklahoma Cooperative Fish and Wildlife Research Unit, Department of Natural Resource

Ecology and Management, Oklahoma State University, Stillwater, Oklahoma 74078, USA

\author{
Andrew T. Taylor \\ Department of Biology, University of Central Oklahoma, Edmond, Oklahoma 73034, USA
}

\author{
Omkar Joshi \\ Department of Natural Resource Ecology and Management, Oklahoma State University, Stillwater, Oklahoma 74078, \\ $U S A$
}

\begin{abstract}
Fishing in streams and rivers is a popular outdoor recreation activity in eastern Oklahoma, where most anglers target black bass (Micropterus) species. Since the early 1990s, when the last assessment of black bass fishing in the region was conducted, broadscale factors such as harvesting behavior, state fishery regulations, and bass population dynamics have changed. In 2018, we conducted creel and fish tagging surveys in three tributaries of Lake Tenkiller (Caney Creek, Baron Fork, and Illinois River) that differed in size and accessibility to provide current estimates of catch, harvest, and effort directed toward black bass. We then related these estimates to angler socioeconomic characteristics. The amount of angler effort was concomitant with stream size and accessibility, being greatest in the largest stream with the most access (Illinois River). However, catch rates were highest in the medium-sized stream (Baron Fork). Harvest rates and exploitation were near zero in all systems. Anglers fishing Caney Creek, the smallest and least accessible stream, were nearly all local, coming from zip codes $\sim 42 \mathrm{~km}$ away, with low median household incomes compared to anglers at the other streams who came from a broader array of more distant zip codes and had higher median household incomes. Anglers fishing the smallest stream were also more interested in harvesting fish and having higher creel limits than anglers at the other two systems. In the Oklahoma Ozark Highlands, stream size and accessibility appear to be a significant factor in angler demographics, potentially necessitating different management strategies.
\end{abstract}

Freshwater fishing is a popular river recreation activity, and black bass Micropterus spp. are highly sought-after freshwater sport fishes for anglers in the United States.
Black bass species are highly prized and are considered trophy fish. Nearly $33 \%$ of the 29.5 million anglers who fish in freshwater outside of the Great Lakes region

*Corresponding author: binod.chapagain@okstate.edu

Received August 12, 2020; accepted December 4, 2020 
collectively spend 117 million days fishing for black bass (U.S. Fish and Wildlife Service and U.S. Census Bureau 2016). While bass fishing is popular across the United States, the southern region has the highest percent of bass anglers among freshwater anglers (Bilgic and Florkowski 2007). State agencies have frequently changed fishing regulations to control overharvesting due to the popularity of bass fishing, although voluntary release has now become a common practice among bass anglers (Long et al. 2015). Since recreational fishing contributes US\$155 billion to the national economy and creates more than 800,000 jobs, black bass fishing has socioeconomic and cultural significance in the United States (American Sportfishing Association 2013).

Although a great number of anglers fish for black bass, the economic activity they devote to their sport can be greater than for anglers pursuing most other freshwater species except trout (Long and Melstrom 2016), resulting in a disproportionate economic impact. However, Oklahoma black bass anglers who fish in streams may spend less to pursue their sport than those who fish in lakes and reservoirs (Long and Melstrom 2016). Regardless, the economic activity of black bass fishing in streams can be substantial, even in a state like Oklahoma where most streams that contain black bass are limited to a small portion of the state. For example, in a previous survey of stream anglers in eastern Oklahoma, 70\% indicated that they targeted black bass, and estimated annual benefits were more than \$24 million (1993 dollars) from stream angling (Fisher et al. 2002).

Considering the importance and popularity of black bass fishing in streams of eastern Oklahoma, little is known about how black bass fishing activities may vary across target species and across streams with different habitat and accessibility characteristics. The most recent studies to characterize black bass fishing in eastern Oklahoma streams were conducted in the early 1990s (Fisher et al. 2002; Martin and Fisher 2009), and those studies focused only on two rivers-Baron Fork (also known as Barren Fork) and Glover River, both of which are state scenic rivers with an emphasis on recreational access. Since that time, factors affecting angler satisfaction, economic benefits from fishing, and the status of black bass populations have changed, necessitating a reevaluation of stream fishing in the region. For instance, harvest rates of black bass in general have plummeted, with voluntary catch-and-release and trophy angling becoming the new norm (Long et al. 2015). Furthermore, black bass regulations in Oklahoma streams have changed from no statewide length limit for any species in 1993-1995 (Martin 1995) to a 229-305-mm TL slot-length limit on Smallmouth Bass Micropterus dolomieu in 2003 (Martin and Fisher 2009), to the 356-mm-TL minimum length limit on Smallmouth Bass and Largemouth Bass $M$. salmoides (with no minimum length on Spotted Bass $M$. punctulatus) that exists currently. Additionally, the number of recognized black bass species has more than doubled, including descriptions of genetically distinct lineages and populations within species (Long et al. 2015; Taylor et al. 2019). Whether stream anglers are knowledgeable and supportive of genetic diversity is unknown, but angler groups (e.g., Bass Anglers Sportsman Society) and some states (e.g., Georgia, Mississippi) have promoted bass fishing "slams," where the goal is to catch all the species, indicating that there is some level of awareness and support.

Among the three native black bass species in Oklahoma (Largemouth Bass [LMB], Smallmouth Bass [SMB], and Spotted Bass [SPB]), SMB is the species most often sought after and caught in streams (Martin and Fisher 2009). In the Ozark Highlands of Oklahoma specifically, the native Smallmouth Bass is a unique subspecies, Neosho Smallmouth Bass M. dolomieu velox (Hubbs and Bailey 1940), which is intolerant of reservoir conditions (Brewer and Long 2015). In the past, to increase Smallmouth Bass abundance in area reservoirs, the Oklahoma Department of Wildlife Conservation stocked a nonnative form, the Tennessee (or "lake-strain") Smallmouth Bass, that was not only tolerant of reservoir conditions, but also had greater growth potential (Fiss et al. 2001; Brewer and Long 2015). However, once the genetic distinctiveness of Neosho Smallmouth Bass was quantified (Stark and Echelle 1998), the Oklahoma Department of Wildlife Conservation ceased their stocking program of the nonnative strain in the Interior Highlands, including the Ozarks. How the pursuit of Neosho Smallmouth Bass, as a component of native biodiversity, influences black bass anglers fishing in streams is unknown. In canals of the central Everglades, a majority of bass anglers were found to prefer targeting native species over nonnative species (Edwards et al. 2016). Currently, black bass stream anglers in the Ozark Highlands of Oklahoma have the opportunity to catch a unique, endemic form of Smallmouth Bass (Neosho Smallmouth Bass) and possibly a nonnative, potentially larger form of Smallmouth Bass (Tennessee lake-strain), but genetic composition varies among locations and possibly stream size (Taylor et al. 2018).

Lake Tenkiller, Oklahoma is one of the reservoirs where nonnative Smallmouth Bass were historically stocked, and evidence exists that these nonnative alleles have introgressed into native populations of upstream tributaries (Taylor et al. 2018). However, the level of introgression into upstream tributaries appeared to be mediated, in part, by stream size. For example, in the Illinois River, which is the primary tributary to Lake Tenkiller, pure, nonnative Smallmouth Bass, in addition to pure, native Neosho Smallmouth Bass, and various levels of hybrids were evident for $55 \mathrm{~km}$ upstream (Taylor et al. 2018). However, in the Baron Fork, which is a tributary to the Illinois River at the Lake Tenkiller river-reservoir 
interface, the incidence of nonnative alleles was much reduced, and almost $90 \%$ of specimens were Neosho Smallmouth Bass (Taylor et al. 2018). Moreover, in Caney Creek, a very small tributary to Lake Tenkiller, nonnative alleles were virtually absent, even though the mouth of the creek was closer to the source of nonnative Smallmouth Bass in the reservoir (Taylor et al. 2018). If anglers prefer pursuing native Neosho Smallmouth Bass, then they might choose to fish these smaller streams over larger ones. However, a multitude of other factors-including fish size, species, expected catch rate, size of the water body, environmental quality, water quality, facility development, and proximity — play a role in determining fishing site quality for anglers when deciding on their fishing locality (Hunt 2005).

Since anglers are a primary steward for sustainable fisheries, understanding their perceptions and attitudes is a very important aspect of fisheries management (Hunt and Grado 2010). Anglers can have different catch-related motivations (e.g., catching numbers of fish, catching preferred sizes of fish, and harvesting fish) depending on factors such as location fished, species targeted, and fishing party (Schroeder and Fulton 2013; Schroeder et al. 2018). Largemouth Bass anglers, for instance, have been found to be more interested in catching big fish and less interested in harvesting fish, whereas Walleye Sander vitreus anglers were highly interested in harvesting fish (Schroeder and Fulton 2013). Similarly, tournament bass anglers place more importance on the catching aspects of fishing than nontournament anglers, who often focus on the noncatching aspects of fishing (Wilde et al. 1998). Investigating angler attitudes and perceptions of black bass fishing in Ozark Highland streams could likewise inform management strategies in the region.

The overarching goal of this study was to compare black bass fishery and angler characteristics among three tributaries of Lake Tenkiller in the Ozark Highlands ecoregion of Oklahoma that vary in size and accessibility. By limiting the study to streams that are in close proximity to each other, we can better control for location effects that may be exhibited by anglers in disparate regions. This study included four primary objectives: (1) to evaluate and compare the fishery characteristics among the streams (e.g., catch rate, fishing effort, and exploitation), (2) to compare socioeconomic characteristics of the anglers, (3) to estimate the economic benefits of black bass fishing in each of these streams, and (4) to compare the anglers' preference for native species and regulatory limits.

\section{METHODS}

Study area.-The study area included three tributaries of Lake Tenkiller: Illinois River, Baron Fork, and Caney Creek in the Ozark Highlands of eastern Oklahoma
(Figure 1), generally referred to hereafter as "streams." The streams in the Ozark region typically have coarse substrates, steep gradients, and clear, cool water. The studied streams differed in length, watershed area, discharge, number of public access points, and designated status (Table 1). The Illinois River is the largest of the three streams with the greatest amount of access points and floating activities (e.g., canoeing, kayaking, rafting), with over 180,000 floaters per year (Meo 2007). Baron Fork and Caney Creek are tributaries of the Illinois River, with Baron Fork being larger than Caney Creek in terms of length, watershed area, and discharge. Public access to Baron Fork is limited to a few bridge-crossing locations that are spaced $\sim 10 \mathrm{~km}$ apart, and public access to Caney Creek is limited to approximately the first $4 \mathrm{~km}$ just upstream of the river-reservoir interface of Tenkiller Lake at a few locations on U.S. Army Corps of Engineersowned property. Moreover, access to the Illinois River tends to be improved, provided immediately adjacent to a paved road with designated parking and maintained bathrooms, whereas access at Baron Fork and Caney Creek is unimproved and accessed by gravel roads. The Illinois River and Baron Fork are "scenic rivers" under the Oklahoma Scenic Rivers Act of 1970. Because these three streams had different characteristics, we expected fishing effort and angler experience to vary. The Illinois River may offer more opportunities to catch larger fish (larger watershed size and higher prevalence of nonnative Smallmouth Bass genes), but conflicts with nonanglers may be a factor due to the large number of floaters (Meo 2007). The Baron Fork has been studied the most and has exhibited some of the highest catch rates of Smallmouth Bass among similar-sized streams (Martin and Fisher 2009). Data on angling at Caney Creek are nonexistent, but numerous streams of a similarly small size offer angling opportunities within the region. Regulations for black bass in these streams were governed by a $356-\mathrm{mm}-\mathrm{TL}$ minimum length limit on Smallmouth Bass and Largemouth Bass with a daily limit of six, in aggregate, of all black bass, although only one may be a Smallmouth Bass. There was no minimum length limit on Spotted Bass.

Creel survey.-We employed a roving creel survey on the Illinois River and Baron Fork while opting for an access point survey on Caney Creek (Pollock et al. 1994) because distance between access points was minimal and water level was too low to float for a roving creel survey (Figure 1). We delineated $29.9 \mathrm{~km}$ of the Illinois River and divided it into two approximately equal subsections, an upper section of $16.3 \mathrm{~km}$ from Chewey Bridge to Peavine Hollow public accesses and a lower section of $13.8 \mathrm{~km}$ from Edmonson to Todd public accesses (Figure 1). Similarly, creel surveys were conducted on a $13.8-\mathrm{km}$ section of Baron Fork from Eldon Bridge to Boy Scout Hole. At Caney Creek, only four public access points were available 


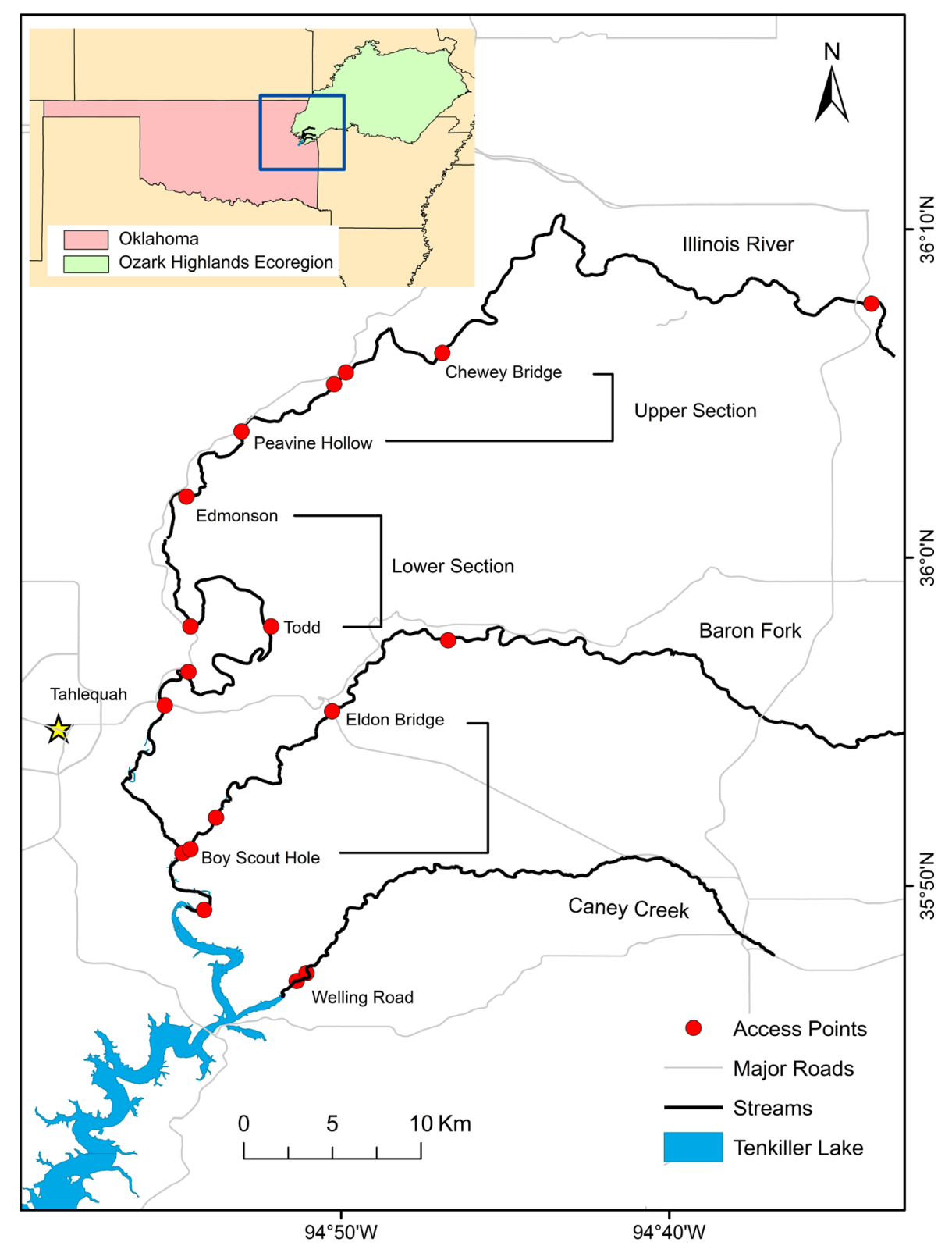

FIGURE 1. Map of studied streams in the Ozark Highlands of Oklahoma. Creel sections and subsections (represented by brackets in Illinois River and Baron Fork) between identified access points are indicated. [Color figure can viewed at afsjournals.org.]

near Welling Road bridge, resulting in a $2.5-\mathrm{km}$ section for creel purposes.

Creel surveys were conducted from May 17 to August 11, 2019, during the season when the preponderance of black bass fishing in streams occurs in this area (Martin and Fisher 2009). As we expected fishing effort to vary within weeks (weekend versus weekday) and days (morning, afternoon, and evening [Ashford et al. 2013]), we used a multistage sampling design based on time period (Pollock et al. 1994; Roop et al. 2018). The primary sampling units were days, which were stratified into weekdays and weekends and holidays. Two weekdays (Thursday and
Friday) and two weekend days and holidays were sampled in each week. The secondary sampling units within each primary sampling unit consisted of two 6-h time blocks designated as morning (0800 to 1400 hours) and afternoon (1400 to 2000 hours). One time block was selected per day, with uniform sampling probability across all primary sampling units, secondary sampling units, and streams. For roving creels, two clerks were assigned to each creel team, with one assigned to interview anglers while the other counted the number of anglers and floaters along the river. For each selected sampling period, clerks floated downstream from the starting point and intercepted 
TABLE 1. Characteristics of streams in the Ozark Highlands of Oklahoma examined for study of black bass angler characteristics.

\begin{tabular}{|c|c|c|c|}
\hline $\begin{array}{l}\text { Stream } \\
\text { characteristics }\end{array}$ & $\begin{array}{l}\text { Caney } \\
\text { Creek }\end{array}$ & $\begin{array}{c}\text { Baron } \\
\text { Fork }\end{array}$ & $\begin{array}{l}\text { Illinois } \\
\text { River }\end{array}$ \\
\hline Length (km) & 36.94 & 55.78 & $233.45^{\mathrm{a}}$ \\
\hline $\begin{array}{l}\text { Watershed area } \\
\text { (square miles) }\end{array}$ & 94 & 343 & 1620 \\
\hline $\begin{array}{l}\text { Water discharge } \\
\left(\mathrm{m}^{3} / \mathrm{s}\right)^{\mathrm{b}}\end{array}$ & 3.16 & 10.85 & 32.81 \\
\hline Public access points ${ }^{\mathrm{c}}$ & Low (4) & Low (4) & High (11) \\
\hline Designation status & None & Scenic river & Scenic river \\
\hline $\begin{array}{l}\text { Floating activities } \\
\text { level }\end{array}$ & Low & Medium & High \\
\hline
\end{tabular}

\footnotetext{
${ }^{\text {aOOnly }} 100 \mathrm{~km}$ located within Oklahoma state boundary.

${ }^{\mathrm{b}}$ Mean discharge between 2014 and 2019.

${ }^{\mathrm{c} P o i n t s}$ within section surveyed; number of access points denoted in parentheses.
}

anglers for interview while they were angling. Progressive counts ("count as you go") of anglers were also conducted by creel clerks to estimate overall effort (Pollock et al. 1994). For the access point survey at Caney Creek, creel clerks moved between the four areas accessible by the public every hour during the creel day, counting and interviewing anglers who were fishing. For all creel surveys, we considered data to be based on incomplete trips. Interviews were used to collect information about an angler's fishing trip, including trip start and expected end times, number of individuals in the fishing party, number of trips in a year, and number of black bass caught as well as size and species of bass harvested. A copy of the creel survey questionnaire is available from authors upon request.

Catch and exploitation. - To estimate catchability (percent of tagged fish caught and released) and exploitation (percent of tagged fish caught and harvested), we marked 949 black bass $>180 \mathrm{~mm}$ TL, which was similar to a previous study in the area (Martin and Fisher 2009), with uniquely identifiable Floy FD-94 tags distributed across streams in proportion to stream size (Illinois River $=591$, Baron Fork $=261$, and Caney Creek $=97$ ) and distributed across species as they were captured during electrofishing surveys $(\mathrm{SMB}=641, \mathrm{LMB}=116, \mathrm{SPB}=191$, and one considered a hybrid). Floy tags had an e-mail address and phone number for reporting catch and harvest of tagged fish, and the phrase "potential reward" was printed on the tag to encourage reporting ( $30 \%$ of all tags were randomly assigned to provide a $\$ 25$ reward). To inform anglers and encourage reporting, we posted signs at access points, along the stream channel, across social media platforms, at public camps, and in local newspapers. The signs instructed anglers of the three ways to report their catch (e-mail, phone, and the iNaturalist app), asking for tag number, date caught, species, stream name, access location, and disposition of the fish (released or harvested). Because we expected a high voluntary release rate $(\sim 80 \%$; Martin and Fisher 2009), we did not require anglers to send in the physical tag and instead instructed them to leave the tag in the fish so we could examine recatchability. Because of the proliferation of smartphones in the past decade, we created a project on the iNaturalist platform, which allowed users to submit a geotagged photo of the catch along with the required catch information, as with e-mail and phone reports (iNaturalist 2020). To estimate tag loss over the creel period, we double-marked fish in Caney Creek, which we presumed to be the less fished site, with PIT tags and resampled in October 2019 to check for presence of Floy and PIT tags.

Anglers' sociodemographic characteristics and opinions.During the creel survey, we asked questions related to anglers' preference for native species and opinions on bag limits and bass size limits in additional to their recreation characteristics (such as trip frequency, distance travelled, cost of traveling, party size, boat or bank fishing method). Similarly, we obtained estimates of anglers' socioeconomic characteristics such as population, income, education, and poverty by zip code or county from U.S. census data (U.S. Census Bureau 2010). The census data provided information about total population, population density, mean household income, income per capita, percentage of people with bachelor's degree, and percentage of people below poverty level associated with the zip code or county of anglers intercepted during creel surveys. We used a three-point Likert scale to measure bass harvesting behavior $(1=$ never, $2=$ sometimes, $3=$ always), amount of fishing activity if native or nonnative Smallmouth Bass were present $(1=$ decrease, $2=$ same, 3 $=$ increase $)$, and opinions on bag and length limits $(1=$ too low, $2=$ just right, $3=$ too high). It is important to note that statewide daily bag and minimum size limits for SMB and LMB is six fish (SMB and LMB combined) and $356 \mathrm{~mm} \mathrm{TL}$, respectively, and there is no bag and length limit for SPB.

We tested angler recreational, sociodemographics, and opinion data for normality with a Shapiro-Francia test (Mbah and Paothong 2015), which showed our data to be nonnormal. As a result, we used nonparametric KruskalWallis tests $(\alpha<0.05)$ to determine significant differences in angler characteristics among the streams, followed by a Dunn's multiple comparison test $(\alpha<0.05)$ with Bonferroni correction to compare stream pairs.

Economic benefit.-The economic benefits to anglers from fishing opportunities in the studied streams can be measured in terms of consumer surplus (CS; also known as willingness to pay or economic value). The CS is the difference between how much an angler is willing to pay and the actual cost $\mathrm{s} / \mathrm{he}$ incurs in accessing the river for 
fishing. The measures of surplus are typically used in calculating economic efficiency of allocating limited government resources to manage recreation opportunities and benefit-cost analysis of resource management (Bowker et al. 2007). We employed the travel cost approach to estimate angler's CS for black bass fishing using annual fishing trips and information regarding distance travelled. This approach is one of the most commonly used methods to measure value of public resources such as fishing. We calculated travel distance as the zip code of the angler's residence, collected during the creel survey, to the angling site (interview location). Two travel cost variables were constructed based on assumptions of wage rate as opportunity cost of time: one was the product of round-trip driving distance and mileage rate plus annual fishing license fee (i.e., zero wage rate), and the second was constructed by adding the product of travel time and onethird of the wage rate on the first variable (Parsons 2017; Chapagain et al. 2018). Following Loomis and McTernan (2014), mean household income was divided by household size and number of working hours (2080) in a year to calculate wage rate. We used the average operating cost of a large sedan, which was $\$ 0.22$ per mile, to calculate mileage rate (American Automobile Association 2019). We used a negative binomial regression model to estimate the demand model of bass fishing and to characterize CS following a commonly used approach in recreational demand modeling (Loomis and McTernan 2014; Parsons 2017). In the regression, the number of bass fishing trips taken in a year was modeled as a function of travel cost and number of anglers in the travelling party. The negative reciprocal of travel-cost coefficient from the estimated regression was used to calculate CS per trip, and CS per person was calculated by dividing the CS per trip value by party size (Parsons 2017). To calculate the confidence interval of CS, we calculated the upper and lower bounds of 95\% confidence interval of travel cost coefficient through bootstrapping the standard errors.

To calculate aggregate CS, we used the monthly fishing effort data. Our study was conducted from mid-May to mid-August, resulting in complete effort data for June and July only. However, Martin and Fisher (2009) and Martin (1995) estimated daily anglers in each month, from April through September at Baron Fork, so we used the percent change in monthly effort from June and July to the closest month in the season, assuming constant fishing hours per anglers in their study period, to predict anglers per day in a month for the fishing season. Considering the close physical geographical proximity of the studied streams, we also estimated daily anglers in each month, assuming that the same proportional changes in effort hold true for Caney Creek and Illinois River. Then, we calculated CS per month in each stream by multiplying CS per person per trip, number of anglers per day, and total days in a month. Finally, we added the monthly aggregate value over the fishing season to calculate aggregate CS for a year.

\section{RESULTS}

We conducted 48 out of 52 planned creel surveysmissed surveys were the result of historic flooding in the region. Creel clerks intercepted 114 anglers during the survey period, with 103 agreeing to participate in the survey for a response rate of $90.1 \%$. During the creel period, an average of $1.54(\mathrm{SD}=1.66), 1.00(\mathrm{SD}=1.35)$, and 2.69 $(\mathrm{SD}=2.56)$ interviews per creel were conducted in Caney Creek, Baron Fork, and Illinois River, respectively. Most anglers were from Oklahoma ( $88 \%$ ), but several were from neighboring states, including Arkansas, Kansas, and Louisiana.

\section{Catch, Effort, and Harvest}

Measures of angling activity varied among streams, but not always concomitant with stream size and accessibility (Table 2). The mean number of anglers per day was highest at Illinois River (32 per day; $\chi^{2}=21.31 ; P<0.05$ ), followed by 9 at Caney Creek and 6 anglers at Baron Fork, which were statistically similar. Likewise, on average, anglers spent nearly $5 \mathrm{~h}$ fishing per trip at the Illinois River $(4.9 \mathrm{~h})$ compared to Baron Fork $(4.3 \mathrm{~h})$ and Caney Creek (2.6 h), with statistically lowest time spent at Caney Creek $\left(\chi^{2}=10.43, P<0.05\right)$ and similar between Illinois River and Baron Fork. However, measures of angling success were greatest at the medium-sized stream, Baron Fork, with a mean catch rate of 3.3 fish per hour. Catch rates at Caney Creek ( $0.8 \mathrm{fish} / \mathrm{h})$ and Illinois River (1.2 fish/h) were significantly lower compared to the rate at Baron Fork. Harvest rates, however, were less than $1 \%$ in all systems. During the creel survey, only three black bass were reported harvested: one Smallmouth Bass from Baron Fork and two from the Illinois River: one of which was a Smallmouth Bass and below the minimum length limit. The other black bass from the Illinois River was not identified or measured.

We were not able to estimate an in situ tag loss rate to correct for tag retention because our resampling of Caney Creek resulted in only one tagged bass (PIT tag, no Floy tag) recaptured out of 94 caught. Additionally, we did not correct for nonreporting rate because the creel clerks did not observe any tagged fish intended for harvest. Regardless, for purposes of comparing among streams, we assumed similar rates of tag retention and reporting and left them uncorrected.

Overall, 155 uniquely tagged fish were reported as caught by anglers (Table 3). Average size of black bass caught was similar among SMB (mean $\mathrm{TL}=286.9 \mathrm{~mm}$; $\mathrm{SD}=78.1$ ), $\mathrm{LMB}$ (mean $\mathrm{TL}=288.9 \mathrm{~mm} ; \mathrm{SD}=74.3$ ), and 


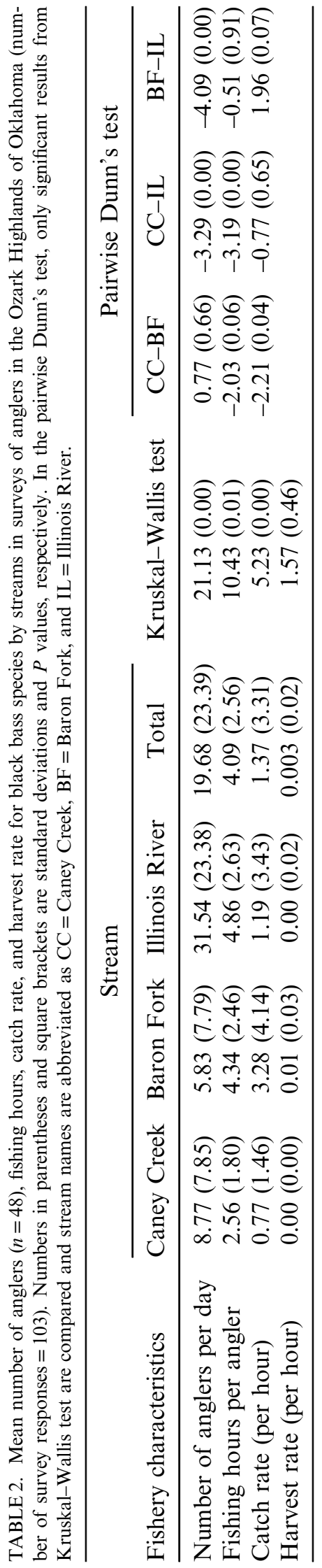


TABLE 3. Catch and harvest exploitation rate by streams and black bass species in the Ozark Highlands of Oklahoma based on tagging results (number of fish tagged $=949$ ). Black bass species are abbreviated as LMB $=$ Largemouth Bass, SMB $=$ Smallmouth Bass, and SPB $=$ Spotted Bass.

\begin{tabular}{|c|c|c|c|c|c|c|}
\hline \multirow[b]{2}{*}{ Species } & \multicolumn{4}{|c|}{ Number of bass } & \multirow[b]{2}{*}{ Catch $(\%)$} & \multirow[b]{2}{*}{ Exploitation (\%) } \\
\hline & Tagged & Caught & Harvested & Recaptured $^{\mathrm{a}}$ & & \\
\hline \multicolumn{7}{|c|}{ Caney Creek } \\
\hline LMB & 12 & 0 & 0 & 0 & 0.0 & 0.0 \\
\hline SMB & 81 & 14 & 1 & 2 & 17.3 & 1.2 \\
\hline SPB & 3 & 0 & 0 & 0 & 0.0 & 0.0 \\
\hline Total & $97^{\mathrm{b}}$ & $15^{\mathrm{b}}$ & 1 & 2 & 15.5 & 1.0 \\
\hline \multicolumn{7}{|c|}{ Baron Fork } \\
\hline LMB & 31 & 4 & 0 & 0 & 12.9 & 0.0 \\
\hline SMB & 213 & 41 & 0 & 10 & 19.2 & 0.0 \\
\hline SPB & 17 & 2 & 0 & 0 & 11.8 & 0.0 \\
\hline Total & 261 & 47 & 0 & 10 & 18.0 & 0.0 \\
\hline \multicolumn{7}{|c|}{ Illinois River } \\
\hline LMB & 73 & 16 & 0 & 1 & 21.9 & 0.0 \\
\hline SMB & 346 & 61 & 1 & 11 & 17.6 & 0.3 \\
\hline SPB & 172 & 16 & 1 & 5 & 9.3 & 0.6 \\
\hline Total & 591 & 93 & 2 & 17 & 15.7 & 0.3 \\
\hline \multicolumn{7}{|c|}{ All study streams } \\
\hline Black bass & 949 & 155 & 3 & 29 & 16.3 & 0.3 \\
\hline
\end{tabular}

${ }^{\mathrm{a}}$ Uniquely tagged fish only; recaptures not considered.

${ }^{\mathrm{b}}$ One fish was considered a hybrid at tagging.

SPB (mean $\mathrm{TL}=296.8 \mathrm{~mm}$; $\mathrm{SD}=68.1$ ). Most tag returns came from the Illinois River (93), followed by 47 returns from Baron Fork and 15 from Caney Creek. In terms of species, 116 returns were SMB, 20 were LMB, and 18 were SPB. Tag returns were reported for all three species in the Illinois River and Baron Fork, whereas only SMB was reported for Caney Creek. Overall, catchability rates were fairly consistent across the streams, averaging 16.33\% (155 caught out of 949 tagged fish). Only three reports from anglers indicated harvesting of bass (two SMB, both under the legal minimum length limit, and one legal-sized SPB), resulting in a combined exploitation rate of less than $1 \%$. Combined across streams and species, we had 29 fish reported as recaptured out of 155 initially captured, for a recapture rate of $18.7 \%$, slightly greater than the $16.33 \%$ rate of initial catchability. From recapture reports, only the Illinois River had species other than SMB reported: 1 LMB recaptured (once), 11 SMB recaptured (all once), and 6 SPB (all once). In Caney Creek, 2 SMB were recaptured (one once and one twice), and in Baron Fork, 10 SMB were recaptured (nine once and one twice).

\section{Recreational and Sociodemographic Characteristics of Anglers in the Studied Streams}

From multiple measures, anglers that fished these three streams were largely segregated by avidity, proximity, and economics. Recreational characteristics such as travel distance, cost of travelling between the angler's residence to fishing site, percentage of anglers using bank fishing, and income level were significantly different between anglers in the three systems (Table 4). In particular, anglers at Baron Fork annually fished for black bass more than anglers at other stream locations and came from zip codes with greater proportions of residents with at least a bachelor's degree, greater amounts of income, and lower rates of poverty (Table 4 ). However, anglers at Baron Fork also took fewer trips to that stream $(13 \%$ of bass fishing trips) than anglers at Illinois River and Caney Creek, who took approximately $30 \%$ of all their bass fishing trips to those systems. Conversely, anglers fishing Caney Creek took significantly shorter trips, spent less for travelling, and came from nearby areas with lower levels of formal education, lower mean household incomes, and greater amounts of poverty. As expected, due to the popularity of the Illinois River for floating, there was a significantly lower proportion of anglers fishing from the bank compared to the other two smaller streams. From our database on tag returns, fewer than $1 \%$ of anglers (4 out of 155) reported catch from more than one system, further indicating that these anglers were largely self-segregating to individual systems.

\section{Economic Benefit Estimates}

On average, the CS for black bass fishing per person and per trip was $\$ 7.86$ and $\$ 16.22$ in the studied streams for the two wage rate assumptions, respectively (Table 5). 


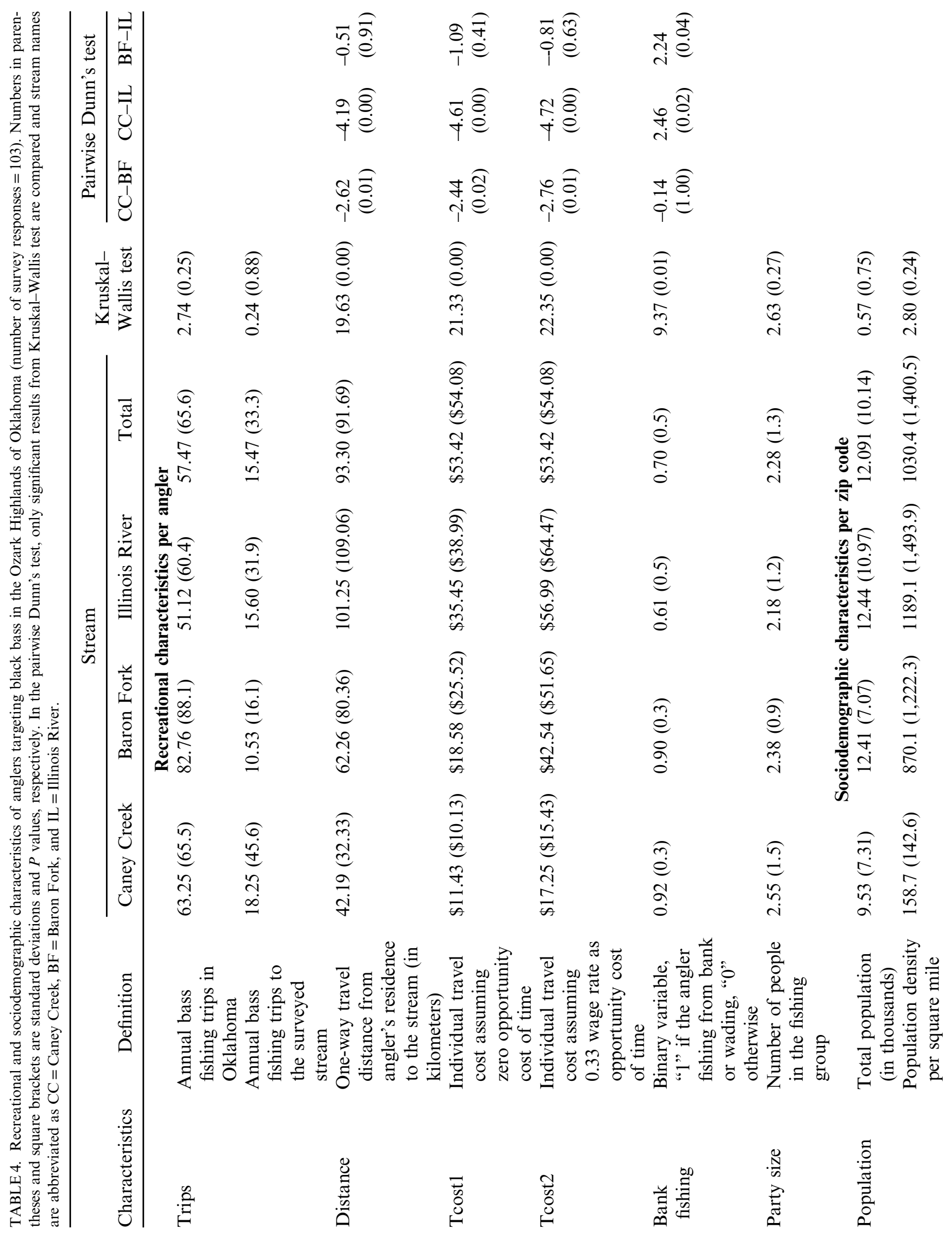




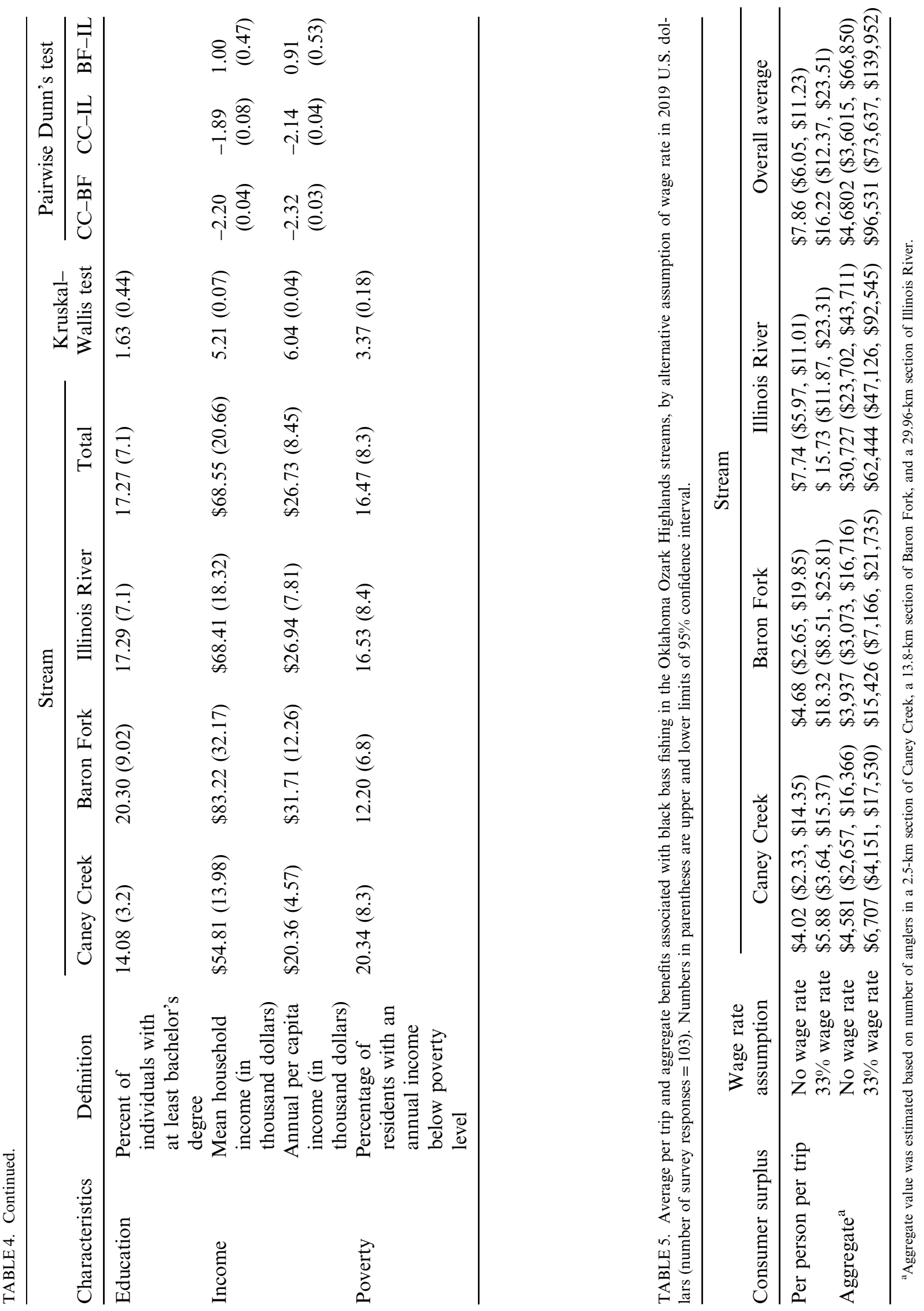


However, the differences in angler demographics translated into different levels of CS among streams. When opportunity cost of time was not assumed, the CS was the highest for anglers fishing the Illinois River at \$7.74. The CS value for Illinois anglers was $\$ 15.73$ when opportunity cost was considered. Similarly, CS was $\$ 4.68$ without assuming opportunity cost and $\$ 18.32$ with opportunity cost considered for Baron Fork anglers, while Caney Creek anglers had the lowest at $\$ 4.02$ without assuming opportunity cost and $\$ 5.88$ with opportunity cost considered. With the $33 \%$ wage rate included, the benefits value was slightly higher for Baron Fork anglers than Illinois River anglers due to higher income for Baron Fork anglers. Because Baron Fork anglers often came from high-income areas, the increase in value from the "no wage rate" scenario to "with wage rate" scenario was $292 \%$, compared to an increase of only $46 \%$ for Caney Creek anglers, demonstrating the role of income on CS estimates and further illustrating the income disparity between anglers at those streams.

The aggregate CS value for the three streams combined was $\$ 46,802$ and $\$ 96,531$, depending on the wage rate assumptions, but individual values for each stream were not equitably distributed (Table 5). Approximately twothirds of the combined aggregate value came from Illinois River anglers, with an aggregate value as high as $\$ 62,444$. Although the number of anglers per day was lowest in Baron Fork, the aggregate value was as high as $\$ 15,426$ due to higher per trip CS. The fishery at Caney Creek had the lowest aggregate value $(\$ 6,707)$ when wage rate was assumed. However, when wage rate was not included, the Caney Creek fishery had a higher value than Baron Fork (\$4,580 compared to $\$ 3,937$ ) because of the higher number of anglers per day at Caney Creek. Considering that the creel survey section for Baron Fork was almost five times longer than Caney Creek, the aggregate benefit per unit length for Caney Creek would be much more than the aggregate benefit for Baron Fork.

\section{Angler Opinions}

Anglers' opinions about harvest and native and nonnative species at each stream were consistent with their demographics (Table 6). Anglers at Caney Creek reported that they kept bass more often $\left(\chi^{2}=10.43, P<0.05\right)$ than anglers at Baron Fork (Dunn's test: $Z=2.63 ; P<0.05$ ) and Illinois River (Dunn's test: $Z=2.01 ; P<0.1$ ). Anglers at Baron Fork were nearly unanimous about "never" harvesting black bass, while anglers at Caney Creek had a more harvest-oriented mindset, with a small percentage saying they "always" harvest black bass. Overall, having native bass in the streams increased angler interest (mean value of 2.23) but the level of interest differed among the three streams $\left(\chi^{2}=9.49, P<0.05\right)$. The majority of anglers at Caney Creek said they would not increase their fishing effort if they knew native bass were present, which differed from anglers at Baron Fork (Dunn's test: $Z=-2.59$; $P<0.05$ ) and Illinois River (Dunn's test: $Z=-2.82$; $P<0.05)$. There were no significant differences among anglers concerning their interest to catch larger, albeit nonnative species, which received a slightly higher mean score of 2.37 compared to the question about native species. Across all three streams, almost all of the anglers considered the current minimum size limit for black bass harvest to be "just right," but differences in opinions on daily bag limit were apparent, with anglers at Caney Creek perceiving the daily harvest limit to be too low.

\section{DISCUSSION}

Our results demonstrate how streams in close proximity to each other but with different characteristics, such as size and accessibility, can have distinct fishery characteristics that are not necessarily proportional with stream size. Moreover, estimates of economic value for each stream demonstrated the interplay between visitation rates and wage rates within the travel cost approach. Although the absolute numbers of anglers scaled with stream size, catch and exploitation were largely consistent across river systems regardless of size. However, the black bass fishery at the smallest stream tended to be composed of anglers from the local area, with low levels of income and a higher disposition to harvest fish than at the other streams, even though observed harvest at the three sites was near zero. Angler characteristics at the two larger sites, Baron Fork and Illinois River, were complex and went beyond simple size scaling.

The level of recreational use and angler characteristics did not scale in proportion with stream size in the Illinois River and Baron Fork, streams designated as scenic rivers by the state. The Illinois River also has much higher usage by nonanglers, being highly developed for canoeing and floating with multiple access points (Meo 2007). At Baron Fork, anglers exhibited very high catch rates, similar to previous findings (Martin and Fisher 2009), while also traveling farther distances from high-income areas to fish. Whether anglers are generally better at catching fish, producing high catch rates, or if high catch rates are an inherent factor of the system, enticing anglers to a fishing destination (e.g., Melstrom et al. 2015), is unknown. In addition, the low number of floaters at Baron Fork could be a factor that influences these anglers from more affluent and distant communities to visit here instead of the Illinois River. Altering fishing behavior in response to crowding, either spatially or temporally, has been observed in reservoir settings (Yow et al. 2008). One angler in our tag return database reported 18 tags (twice as much as the next angler), all from the Illinois River in close proximity to his home, and he indicated that he 
TABLE 6. Anglers' opinion about keeping the black bass that they caught, interest in native and nonnative bass, and opinion about minimum size and daily harvest limit by stream in the Ozark Highlands of Oklahoma (number of survey responses $=103$ ). Numbers in parentheses and square brackets are standard deviations and $P$ values, respectively. In the pairwise Dunn's test, only significant results from Kruskal-Wallis test are compared.

\begin{tabular}{|c|c|c|c|c|c|c|c|c|}
\hline \multirow[b]{2}{*}{ Opinion } & \multicolumn{4}{|c|}{ Stream } & \multirow[b]{2}{*}{$\begin{array}{l}\text { Kruskal- } \\
\text { Wallis test }\end{array}$} & \multicolumn{3}{|c|}{ Pairwise Dunn's test } \\
\hline & $\begin{array}{l}\text { Caney } \\
\text { Creek }\end{array}$ & $\begin{array}{l}\text { Baron } \\
\text { Fork }\end{array}$ & $\begin{array}{l}\text { Illinois } \\
\text { River }\end{array}$ & Total & & $\mathrm{CC}-\mathrm{BF}$ & CC-IL & $\mathrm{BF}-\mathrm{IL}$ \\
\hline Keeping black bass ${ }^{\mathrm{a}}$ & $1.55(0.6)$ & $1.07(0.3)$ & $1.28(0.5)$ & $1.31(0.5)$ & $7.27(0.03)$ & $2.63(0.01)$ & $2.01(0.07)$ & $-1.41(0.24)$ \\
\hline $\begin{array}{l}\text { Interest in } \\
\text { native species }\end{array}$ & $1.95(0.2)$ & $2.38(0.5)$ & $2.28(0.5)$ & $2.23(0.5)$ & $9.49(0.01)$ & $-2.59(0.01)$ & $-2.82(0.01)$ & $0.69(0.73)$ \\
\hline $\begin{array}{l}\text { Interest in } \\
\text { larger, but } \\
\text { nonnative species }{ }^{\mathrm{c}}\end{array}$ & $2.30(0.5)$ & $2.61(0.5)$ & $2.35(0.5)$ & $2.37(0.5)$ & $3.50(0.17)$ & & & \\
\hline $\begin{array}{l}\text { Minimum } \\
\text { length limit }^{\mathrm{d}}\end{array}$ & $2.20(0.6)$ & $1.88(0.3)$ & $2.00(0.4)$ & $2.02(0.5)$ & $3.12(2.11)$ & & & \\
\hline Daily harvest limit ${ }^{\mathrm{e}}$ & $1.61(0.5)$ & $2.22(0.4)$ & $2.08(0.4)$ & $2.01(0.5)$ & $11.12(0.00)$ & $-2.85(0.01)$ & $-3.04(0.00)$ & $0.80(0.63)$ \\
\hline
\end{tabular}

\footnotetext{
aResponse to survey item: "How often do you keep the black bass that you catch in streams?" Item measured on a 3-point Likert scale $(1=$ never, $2=$ sometimes, $3=$ always).

${ }^{\text {b}}$ Response to survey item: "How does having a unique subspecies of Smallmouth Bass in the river influence your fishing interest for bass?" Item measured on 3-point Likert scale $(1=$ decrease, $2=$ same, $3=$ increase $)$.

${ }^{\text {'} R e s p o n s e ~ t o ~ s u r v e y ~ i t e m: ~ " H o w ~ d o e s ~ h a v i n g ~ n o n n a t i v e ~ S m a l l m o u t h ~ B a s s ~ i n ~ t h e ~ r i v e r ~ i n f l u e n c e ~ y o u r ~ f i s h i n g ~ i n t e r e s t ~ f o r ~ b a s s ? " ~ I t e m ~ m e a s u r e d ~ o n ~ 3-p o i n t ~ L i k e r t ~ s c a l e ~}$ $(1=$ decrease, $2=$ same, $3=$ increase $)$.

${ }^{\mathrm{d}}$ Response to survey item: "What is your opinion regarding minimum length limit of 14 in for Largemouth and Smallmouth bass?" Item measured on 3-point Likert scale $(1=$ too low, $2=$ just right, $3=$ too high $)$.

'Response to survey item: "What is your opinion regarding daily harvest limit of six fish for Largemouth and Smallmouth bass combined?" Item measured on 3-point Likert scale $(1=$ too low, $2=$ just right, $3=$ too high $)$.
}

alters his fishing behavior temporally by fishing before the peak of floating activity. Further research on angler motivation, site choice characteristics, and how crowding influences fishing activity on streams is needed to better parse these questions.

A stark dichotomy existed between angler characteristics at Caney Creek and the other two streams in our study area. Anglers at this site were more likely to want to keep bass and less interested in increasing fishing if they were aware of native bass presence, and they had stronger desire for higher daily harvest limits, all of which suggest a higher harvest orientation. These anglers were primarily local and were from areas with lower levels of income and education. They also exhibited high visitation rates to this system. When present at the stream, these anglers spent less time fishing per trip, with limited public access in a smaller stream, which reduces the stream length available for fishing. If our estimates of CS are an indicator of economic importance of streams to the anglers, then the inclusion of wage rate (as opportunity cost of time) is vital in comparing benefits of bass fishing to anglers in each stream. For example, without the wage rate assumption in travel cost construction, Caney Creek exhibited slightly lower CS values than Baron Fork. Because the vast majority of anglers were observed fishing only one creek, this suggests that anglers at Caney Creek have a high attachment to this place with few replacement options, and Caney Creek anglers had more than one-third of the total annual bass fishing visits to the stream. Here, a higher frequency of trips is generating more CS despite anglers living close to the stream. The percentage increase in value in the model with wage rate assumption was the lowest $(46 \%)$ for Caney Creek anglers, in accordance with their lower income level and less impact of income on CS. On the other hand, household income or wage rate resulted in more CS in Baron Fork when wage rate was assumed as an opportunity cost of time. In concert, this demonstrates that small, locally accessible places can have high value in comparison to larger systems that attract nonlocal visitors.

Although per trip CS increased with stream size and accessibility, aggregate values did not change with respect to stream size, suggesting an important role of per trip value and angler numbers in aggregate economic benefits from each stream. For example, the smaller Caney Creek provided higher economic benefits (when wage rate was not considered) than Baron Fork due to a higher number of anglers. In comparison to our estimates, Bilgic and Florkowki (2007) found a per CS of \$161 (1996 dollars) for black bass fishing based on off-site data from the southern United States. Their estimated value is very high because the majority of anglers fished in lakes and ponds in their study and they included all the trip-related expenditures (food, travel, and lodging) as travel cost, an important factor in determining CS. In our study, we surveyed only stream anglers using on-site surveys in which 
frequent visitors (i.e., anglers live close to studied streams) are more likely to be interviewed, and we only considered mileage rate (based on cost of gas and depreciation) and fishing license fee to calculate travel cost, a commonly used approach in travel cost modeling.

Our findings demonstrate the economic benefits of maintaining black bass fishing opportunities in eastern Oklahoma streams. The results present important implications related to informing management and policy. The aggregate benefits values suggest that anglers would incur a significant welfare loss if fishing opportunities in the study streams were lost. These values can be a subject of interest to the agencies who have mandates to sustain fishing for recreation and rural economic development. Estimates for economic benefits per trip could be used for other streams and rivers in Oklahoma and the United States to approximate the economic value of black bass fishing opportunities through a benefit-transfer approach and to compare with cost associated with managing fishing opportunities.

Our results indicated near-zero harvest of black bass across the Ozark streams in three study streams, according to both creel survey and tag return results. High voluntary release rates of black bass have been the norm since the late 1990s (Quinn 1996; Long et al. 2015), but most of the evidence comes from lakes and reservoirs. At one of our study streams, Baron Fork, where previous data are available, exploitation of black bass was low in the early 1990s at an average of $7 \%$ (assuming 100\% reporting rate; Martin and Fisher 2009). Our current estimate of black bass exploitation at Baron Fork was 0\% (also assuming 100\% reporting rate and tag retention). Moreover, at all three sites in our study combined, exploitation of black bass was $0.3 \%$. The size of fish tagged $(\geq 180 \mathrm{~mm} \mathrm{TL})$ resulted in approximately $69 \%$ of fish being below legal harvest size $(356 \mathrm{~mm}$ TL for Smallmouth Bass and Largemouth Bass). However, fish size did not impact estimates of exploitation appreciably. Considering only legal-size fish for harvest, exploitation increased from $0.3 \%$ to only $0.4 \%$ (Joshi et al. 2020). These findings are consistent with other recently conducted studies in Ozark streams. For example, harvest rates of Smallmouth Bass at the Buffalo River, Arkansas were reported as $0.29 \mathrm{fish} / \mathrm{h}$ in 1981-1982, 0.06 $\mathrm{fish} / \mathrm{h}$ in 1991-1992 (Johnson 1995), and $0.001 \mathrm{fish} / \mathrm{h}$ in 2013-2014 (Todd and Hodges 2018). From the latest estimate at Buffalo River, we can infer an exploitation rate of $0.2 \%$, calculated as the proportion of estimated fish harvested (321) over estimated fish caught $(146,000)$ in their study. These near-zero harvest rate estimates also appear to be the case for two other Ozark streams in Arkansas currently being studied (J. Risley, Arkansas Game and Fish Commission, personal communication). Across all these recent studies, it thus appears that black bass harvest has declined to minimal levels in streams throughout the
Ozarks, although variation among individual streams is a possibility (e.g., Isermann et al. 2013).

Although our estimates of catchability and exploitation are comparable among streams without correction, the effects of tag retention and reporting rates would affect these estimates and make them conservative. In a previous study at Baron Fork, Martin and Fisher (2009) assumed a $64 \%$ tag reporting rate, based on results from a study that used postcards to estimate return rate at another system in Tennessee (Weathers and Bain 1992). Our estimates, based on a small number of anglers who reported to the creel clerks that they caught tagged fish, ranged from $67 \%$ ( 2 of 3 anglers reported to the tag database) to $71 \%$ (5 of 7 tag numbers correctly reported to the tag database). Similarly, we were unable to correct for tag loss. Using similar tags (Floy FD-94), Gurtin et al. (1999) reported tag retention of $88 \%$ to $92 \%$ in Largemouth Bass up to $512 \mathrm{~d}$ at large. Moreover, in a study of Smallmouth Bass, retention of Floy FD-94 anchor tags ranged from 96\% to $100 \%$ up to $109 \mathrm{~d}$ posttagging, with a notable exception where retention was $73 \%$ over $120 \mathrm{~d}$, but tagging issues there were resolved the following year, bringing the rate to $100 \%$ over $186 \mathrm{~d}$ (Breton et al. 2014). Our study lasted $211 \mathrm{~d}$ from first tagging to the end on the reporting period, suggesting that tag retention could be on the lower side of these estimates, which were still quite high. In effect, using the lowest rates for tag reporting $(64 \%)$ and tag retention $(73 \%)$, our estimates of total catchability would increase from $16.3 \%$ to $35 \%$ and exploitation from $0.3 \%$ to $0.7 \%$. However, using our information on recaptured fish (fish caught by anglers at least once after being reported once before; $N=29$ ) in relation to captured fish (individual fish ever captured by anglers; $N=155$ ), recatchability is $18.7 \%$, which is similar to the $16.3 \%$ catchability rate for all individual tagged fish (155 captured out of 949 tagged). This recatchability estimate suggests minimal corrections for tag retention and reporting would be warranted.

Stream fisheries management requires information about use of resources and how anglers value the resources with which they interact. Since few studies have investigated such information in Oklahoma streams, and the last study was conducted almost two decades ago, findings from this study have important management implications. For example, fisheries managers may find spatial variation in angler characteristics useful to set management priorities, such as to protect native fish populations (for example, Neosho Smallmouth Bass), promote areas with high catch rates or potential for trophy angling, or provide opportunities for fishing in solitude with little potential for crowding. Across the region, this suggests a resilience approach to fisheries management (Pope et al. 2014) where a variety of fishing conditions are maintained to promote sustainability across the region. For example, 
native Neosho Smallmouth Bass are more prevalent in Baron Fork and Caney Creek, and evidence suggests that Caney Creek may be less susceptible to invasion by the nonnative strain of Smallmouth Bass (Taylor et al. 2018). However, anglers at Caney Creek were generally not interested in increasing fishing based on the knowledge that native Smallmouth Bass were present. Thus, conserving this strain at this location could involve information strategies that focus on abundance or catch rates-which are typically high for Neosho Smallmouth Bass streamsinstead of nativity for these anglers. Conversely, outreach messages that promote the knowledge of native Neosho Smallmouth Bass at Baron Fork would likely be perceived more positively and probably reach a larger audience, due to the nature of this system attracting anglers from a larger part of the state. Furthermore, because Neosho Smallmouth Bass may not grow as large as the nonnative Tennessee strain (Brewer and Long 2015), promotion of fishing activities at the Illinois River could involve highlighting trophy fish potential where a greater proportion of nonnative Smallmouth Bass occur (Taylor et al. 2018). The differences among streams with regard to fishery and recreational characteristics suggest that separate approaches could be used for bass management in these streams, although more research would be needed to find a broader basis for such a system throughout the region or the state. Using sociodemographic information while designing and planning management actions regarding black bass fishing in streams could allow for more effective and efficient conservation programs.

\section{ACKNOWLEDGMENTS}

This project was funded by the Oklahoma Department of Wildlife Conservation through the Sport Fish and Wildlife Restoration Program F18AF00659 (F-106-R-1). Oklahoma State University's Institutional Review Board approved the final survey instrument and protocols (AG19-12), and the Oklahoma State University Institutional Animal Care and Use Committee approved the fish handling and tagging procedures (AG-19-3). We thank J. Burroughs, T. Starks, A. Rodger, D. King, and A. Gonzalez for help tagging fish. C. Waldorf, E. Rice, and K. Locke conducted the creel surveys, and L. Warnock provided access to Baron Fork. We thank E. Fite and staff of the Grand River Dam Authority (GRDA) Scenic Rivers Operations for logistical support. The Oklahoma Cooperative Fish and Wildlife Research Unit is supported by the Oklahoma Department of Wildlife Conservation, Oklahoma State University, U.S. Geological Survey, the Wildlife Management Institute, and the U.S. Fish and Wildlife Service. There is no conflict of interest declared in this article. Any use of trade, firm, or product names is for descriptive purposes only and does not imply endorsement by the U.S. Government. There is no conflict of interest declared in this article.

\section{ORCID}

Binod P. Chapagain (iD http://orcid.org/0000-0002-39006990

James M. Long (D) https://orcid.org/0000-0002-8658-9949

Andrew T. Taylor (iD https://orcid.org/0000-0002-8491-

9967

Omkar Joshi (D) http://orcid.org/0000-0002-3254-6628

\section{REFERENCES}

American Automobile Association. 2019. Your driving cost. American Automobile Association, Heathrow, Florida. Available: https://excha nge.aaa.com/automotive/driving-costs/\#.X_f3T9hKg2w. (March 2020).

American Sportfishing Association. 2013. Sportfishing in America: an economic force for coservation. American Sportfishing Association, Alexandria, Virginia. Available: https://asafishing.org/uploads/2011_ ASASportfishing_in_America_Report_January_2013.pdf. (May 2020).

Ashford, J. R., C. M. Jones, and L. Fegley. 2013. Within-day variability in catch taken by public access fishers during a recreational fishing survey. Transactions of the American Fisheries Society 142:974-978.

Bowker, J. M., J. C. Bergstrom, and J. Gill. 2007. Estimating the economic value and impacts of recreational trails: a case study of the Virginia Creeper Rail Trail. Tourism Economics 13:241-260.

Breton, A. R., D. L. Winkelman, J. A. Hawkins, and K. R. Bestgen. 2014. Population trends of Smallmouth Bass in the upper Colorado River basin with an evaluation of removal effects. Final Report to the Upper Colorado River Endangered Fish Recovery Program, Larval Fish Laboratory Contribution 169, Denver.

Brewer, S. K., and J. M. Long. 2015. Biology and ecology of Neosho Smallmouth Bass and the genetically distinct Ouachita lineage. Pages 281-296 in M. D. Trigali, J. M. Long, T. W. Birdsong, and M. S. Allen, editors. Black bass diversity: multidisciplinary science for conservation. American Fisheries Society, Symposium 82, Besthesda, Maryland.

Chapagain, B. P., N. C. Poudyal, J. Bowker, A. E. Askew, D. B. English, and D. G. Hodges. 2018. Potential effects of climate on downhill skiing and snowboarding demand and value at U.S. national forests. Journal of Park and Recreation Administration 36:75-96.

Edwards, C. J., J. T. Heinen, and J. S. Rehage. 2016. Recreational angler perspectives of nonnative fishes. Human Dimensions of Wildlife 21:144-157.

Fisher, W. L., D. Schreiner, C. Martin, Y. Negash, and E. Kessler. 2002. Recreational fishing and socioeconomic characteristics of eastern Oklahoma stream anglers. Proceedings of the Oklahoma Academy of Science 82:79-87.

Fiss, F. C., T. A. Cleveland, B. D. Carter, R. D. Bivens, and J. M. Swearengin. 2001. Population characteristics of riverine Smallmouth Bass in Tennessee, simulated effects of length limits, and management recommendations. Tennessee Wildlife Resources Agency, Fisheries Report, 01-19, Nashville.

Gurtin, S. D., M. L. Brown, and C. G. Scalet. 1999. Retention of Floy FD94 anchor tags and effect on growth and condition of Northern Pike and Largemouth Bass. Journal of Freshwater Ecology 14:281-286.

Hubbs, C. L., and R. M. Bailey. 1940. A revision of the black basses (Micropterus and Huro) with descriptions of four new forms. Miscellaneous Publications Museum of Zoology University of Michigan 48.

Hunt, K. M., and S. C. Grado. 2010. Use of social and economic information in fisheries assessments. Pages 425-447 in W. A. Hubert and 
M. C. Quist, editors. Inland fisheries management in North America, 3rd edition. American Fisheries Society, Bethesda, Maryland.

Hunt, L. M. 2005. Recreational fishing site choice models: insights and future opportunities. Human Dimensions of Wildlife 10:153-172.

iNaturalist. 2020. A community of naturalists. Available: https://www.ina turalist.org/. (July 2019).

Isermann, D. A., J. B. Maxwell, and M. C. McInerny. 2013. Temporal and regional trends in black bass release rates in Minnesota. North American Journal of Fisheries Management 33:344-350.

Johnson, J. E. 1995. Recreational and angler survey of the Buffalo National River, Arkansas. Journal of the Arkansas Academy of Science 49:82-86.

Joshi, O., A. T. Taylor, and B. Chapagain. 2020. Black bass angler harvest and opinions in relation to stream size, access, and fish diversity. Oklahoma Department of Wildlife Conservation, Final Report F18AF00659, Oklahoma City.

Long, J. M., and R. T. Melstrom. 2016. Measuring the relationship between sportfishing trip expenditures and anglers' species preferences. North American Journal of Fisheries Management 36:731-737.

Long, M., W. P. Allen, and C. D. Suski. 2015. A historical perspective of black bass management in the United States. Pages 99-122 in M. D. Tringali, J. M. Long, T. W. Birdsong, and M. S. Allen, editors. Black bass diversity: multidisciplinary science for conservation. American Fisheries Society, Symposium 82, Bethesda, Maryland.

Loomis, J., and J. McTernan. 2014. Economic value of instream flow for non-commercial whitewater boating using recreation demand and contingent valuation methods. Environmental Management 53:510519.

Martin and Fisher. 2009. Recreational fishing for black bass in eastern Oklahoma streams. Proceedings of the Annual Conference Southeastern Association of Fish and Wildlife Agencies 62:168-176.

Martin, C. D. 1995. Comparisons between Ozark and Ouachita stream fisheries in eastern Oklahoma. Master's thesis. Oklahoma State University, Stillwater.

Mbah, A. K., and A. Paothong. 2015. Shapiro-Francia test compared to other normality test using expected $p$-value. Journal of Statistical Computation and Simulation 85:3002-3016.

Melstrom, R. T., D. Jayasekera, C. Jager, and T. A. Boyer. 2015. The economic value of sportfishing trips to Oklahoma lakes. Oklahoma Cooperative Extension Service, Fact Sheet: AGEC-1054, Stillwater.

Meo, M. 2007. The Illinois River Project and Oklahoma's quest for environmental quality. Journal of Contemporary Water Research and Education 136:56-67.

Parsons, G. R. 2017. Travel cost models. Pages 269-329 in P. A. Champ, T. C. Brown, and K. J. Boyle editors. A primer on nonmarket valuation. Springer, Dordrecht, The Netherlands.

Pollock, K. H., C. M. Jones, and T. L. Brown. 1994. Angler survey methods and their application in fisheries management. American Fisheries Society, Special Publication 25, Bethesda, Maryland.
Pope, K. L., C. R. Allen, and D. G. Angeler. 2014. Fishing for resilience. Transactions of the American Fisheries Society 143:467-478.

Quinn, S. 1996. Trends in regulatory and voluntary catch-and-release fishing. Pages 152-162 in L. E. Miranda and D. R. DeVries, editors. Multidimensional approaches to reservoir fisheries management. American Fisheries Society, Symposium 16, Bethesda, Maryland.

Roop, H. J., N. C. Poudyal, and C. A. Jennings. 2018. Assessing angler effort, catch, and harvest on a spatially complex, multi-lake fishery in middle Georgia. North American Journal of Fisheries Management 38:833-841.

Schroeder, S. A., and D. C. Fulton. 2013. Comparing catch orientation among Minnesota Walleye, Northern Pike, and bass anglers. Human Dimensions of Wildlife 18:355-372.

Schroeder, S. A., D. C. Fulton, E. Altena, H. Baird, D. Dieterman, and M. Jennings. 2018. The influence of angler values, involvement, catch orientation, satisfaction, agency trust, and demographics on support for habitat protection and restoration versus stocking in publicly managed waters. Environmental Management 62:665-677.

Stark, W. J., and A. A. Echelle. 1998. Genetic structure and systematics of Smallmouth Bass, with emphasis on Interior Highlands populations. Transactions of the American Fisheries Society 127:393-416.

Taylor, A. T., J. M. Long, M. R. Schwemm, and S. K. Brewer. 2018. Hybridization and genetic structure of Neosho Smallmouth Bass in the Ozark Highlands. North American Journal of Fisheries Management 38:1226-1240.

Taylor, A. T., J. M. Long, M. D. Tringali, and B. L. Barthel. 2019. Conservation of black bass diversity: an emerging management paradigm. Fisheries 44:20-36.

Todd, S., and S. Hodges. 2018. Buffalo River floating use and angler creel survey 9/1/2013-8/31/2014. Arkansas Game and Fish Commission, Final Report, Little Rock.

U.S. Census Bureau. 2010. American community survey 5-year estimates. Available: https://data.census.gov/cedsci/. (October 2019).

U.S. Fish and Wildlife Service and U.S. Census Bureau. 2016. 2016 national survey of fishing, hunting, and wildlife-associated recreation. U.S. Fish and Wildlife Service, Washington, D.C.

Weathers, K. C., and M. B. Bain. 1992. Smallmouth Bass in the Shoals Reach of the Tennessee River: population characteristics and sport fishery. North American Journal of Fisheries Management 12:528-537.

Wilde, G. R., R. K. Riechers, and R. B. Ditton. 1998. Differences in attitudes, fishing motives, and demographic characteristics between tournament and nontournament black bass anglers in Texas. North American Journal of Fisheries Management 18:422-431.

Yow, D. L., K. B. Hodges, A. P. Wheeler, and J. M. Rash. 2008. Crowding and response: angler perceptions on western North Carolina reservoirs. Pages 231-245 in M. S. Allen, S. M. Sammons, and M. J. Maceina, editors. Balancing fisheries management and water uses for impounded river systems. American Fisheries Society, Symposium 62, Bethesda, Maryland. 